\title{
Response of Vegetation of the Northern Great Plains to Precipitation Amount and Grazing Intensity
}

\author{
KENNETH C. OLSON, RICHARD S. WHITE, AND BRIAN W. SINDELAR
}

\begin{abstract}
Changes in basal cover of vegetation were predicted in response to variation in precipitation and grazing intensity. Multiple regression analysis was used with basal cover as a dependent variable and precipitation parameters as independent variables to develop predictive equations. Predicted cover values were used to develop three dimensional response surfaces which describe individual species responses to fluctuating precipitation and different grazing intensities. Results indicate that each species reacts to precipitation regimes and grazing pressure in a unique manner. Continual changes in basal cover can be expected in the plant community as the precipitation regime changes. Moderate grazing intensity, approximately $0.92 \mathrm{ha}$ ( 2.3 acres) per $\mathrm{AUM}$, appears to be most conducive for maintaining vegetative cover that is desirable for livestock production. However, stocking rate changes need to be anticipated and planned to coincide with available forage because of large fluctuations in cover due to varying precipitation.
\end{abstract}

Climate appears to be the major factor controlling plant growth in the Great Plains. Whitman et al. (1943) stated that drought is the primary influence of vegetational change. Reed and Peterson (1961), Hurtt (1951), and Clark et al. (1943) stated that major trends in vegetation are primarily determined by fluctuations in climatic conditions, and that changes within these major trends are influenced by grazing intensity.

Authors are former graduate student, Department of Animal and Range Sciences, Montana State University, Bozeman 59717; research plant physiologist, USDA-ARS, Livestock and Range Research Station, Route, I Box 2021, Miles City, Mont. 59301; and assistant professor, Department of Animal and Range Sciences, Montana State University, Bozeman 59717, respectively.

The research is a contribution from the Western Region, USDA-ARS, Livestock and Range Research Station and the Montana Agricultural Experiment Station, Journal Series No. J-1445.

Manuscript accepted January 2, 1985.
There is a close relationship between time and amount of precipitation and plant growth (Albertson et al. 1953). One wet or dry year will affect production, but 2 or more wet or dry years are required to change the basal cover (Johnson 1981). Abrupt and funda mental changes in the amount and kind of living plant crown area may result from severe drought and last longer than anticipated (Reed and Peterson 1961). Both frequency and duration of drought are important in determining the severity of effects of climate on vegetation (Cook and Sims 1975, Herbel et al. 1972).

Native vegetation has developed under conditions of wide climatic variation (Albertson et al. 1957). Marked changes in botanical composition occur, but plant populations are seldom completely destroyed by climatic fluctuation (Cook and Sims 1975). These changes are slow, whether for better or worse (Sarvis 1941). Native grass species will remain dominant in prairies unless they are severely grazed or buried by dust (Cook and Sims 1975, Schumacher 1974, Albertson et al. 1957).

A more comprehensive understanding of the responses of range ecosystems to weather and grazing is desirable for good management (Reed and Peterson 1961). Drought cannot be controlled, but its impact can be moderated by proper livestock management. To do this, changes in plant communities need to be better defined so that effects of both drought and above average precipitation can be anticipated on the range. There are general ideas of the influence of precipitation and grazing intensity on rangeland plant communities, but only limited effort has been made to predict the responses within plant communities to fluctuating precipitation regimes and different grazing intensities. Models have been developed to predict forage production at different levels of precipitation (Smoliak 1956, Sneva and Hyder 1962, Abel et al. 1962), but similar endeavors that evaluate plant cover response to fluctuating precipitation 
and grazing intensity have not been undertaken. Predictive models that estimate forage production are very useful for determining stocking rates. However, a more concise understanding of changing ecological roles of plant species can be achieved by determining changes in basal cover of the plant species; and hence, a better understanding of community dynamics of range ecosystems can be realized.

The purpose of this study was to describe quantitative changes in basal cover of vegetation in response to variation in precipitation amount and grazing intensity. Specific objectives were: (1) to investigate the relationship between plant basal cover and amount of precipitation; (2) to examine the effect of grazing intensity superimposed on the relationship between plant basal cover and a mount of precipitation; and (3) to evaluate the use of multiple regression as a method to examine these relationships and effects.

\section{Methods and Procedures}

Data were compiled over a 25-year period (1932 to 1956), at the Livestock and Range Research Station near Miles City, Mont. Cattle grazed 3 pairs of pastures of unequal size for a 6-month period from mid-May to mid-November each year. Three rates of stocking were provided by assigning 10 cows to each pasture. The stocking rates were 0.76 ha ( 1.9 acres) per animal unit month (AUM) for heavy grazing, 0.92 ha (2.3 acres) per AUM for moderate grazing, and 1.24 ha (3.1 acres) per AUM for light grazing. ${ }^{1} \mathrm{~A}$

\footnotetext{
In general, the AUM stocking rate was consistent with that of the classical definition. That is, it was defined as a $454 \mathrm{~kg}(1,000 \mathrm{lb})$ cow with calf grazing for a period of one month. It should be noted that small annual variations occurred over the 25 -year period with respect to either cow size or calf crop. However, such deviations were not regarded as having a significant impact on forage utilization (Holscher and Woolfolk 1953).
}

fourth stocking rate with no livestock grazing was provided by fenced exclosures within individual pastures.

Basal cover data were collected during early and midsummer using the pantograph method (Hill 1920, Weaver and Clements 1938). A total of 43 permanent square meter pantograph plots were distributed throughout the pastures to monitor plant response under the 3 stocking rates and in ungrazed exclosures. For further information concerning the character and design of this study, see Reed and Peterson (1961), Hurtt (1951), and Houston and Woodward (1966).

A total of 142 species was recorded on the pantograph plots throughout the 25-year period of the study. Many species were eliminated from further study because they occurred rarely or showed little relationship between basal cover and precipitation. Elimination was based on visual comparison of graphs which displayed the cover response of individual species to annual precipitation. Multiple regression analyses were then employed for species that showed a visual relationship, and predictive equations were developed which related basal cover of individual species to precipitation. Independent variables included precipitation amounts from the current and preceding year examined with respect to 3 different intervals: on a calendar year basis, on an annual basis of 1 November through 31 October (plant-year precipitation), and for the normal growing season interval (i.e., monthly periods, April through May). Linear and quadratic responses were evaluated along with all associated interactions for each of the precipitation intervals noted.

The regression equations that were obtained were evaluated for their ability to predict basal cover and in order to determine which precipitation variables yielded the highest coefficient of multiple

Table 1. Comparison of $\boldsymbol{R}^{2}$ values obtained using calendar-year, plant-year and growing-season precipitation as independent variables and plant basal cover as the dependent variable.

\begin{tabular}{|c|c|c|c|}
\hline \multirow[b]{3}{*}{ Species or group } & \multicolumn{3}{|c|}{$R^{2}$} \\
\hline & \multicolumn{3}{|c|}{ Precipitation Regime } \\
\hline & Calendar-year & Plant-year' & Growing-season \\
\hline Western yarrow (Achillea millefolium) & .27 & & \\
\hline Western wheatgrass (Agropyron smithii) & .71 & .76 & .83 \\
\hline Red Threeawn (Aristida longiseta) & .74 & .76 & .83 \\
\hline Silver sagebrush (Artemisia cana Pursh.) & .18 & & \\
\hline Fringed sagewort (A. frigida) & .66 & .62 & .71 \\
\hline Big sagebrush (A. tridentata Nutt.) & .10 & & \\
\hline Blue grama (Bouteloua gracilis) & .52 & & \\
\hline Buffalograss (Buchloe dactyloides) & .77 & .83 & .59 \\
\hline Threadleaf sedge (Carex filifolia) & .44 & & \\
\hline Needleleaf sedge (C. eleocharis) & .50 & & \\
\hline Six weeks grass (Vulpia octoflora (Wolf) Rydb.) & .35 & & \\
\hline Pincushion cactus (Mammilaria missouriensis Sweet.) & .21 & & \\
\hline Plains pricklypear (Opuntia polyacantha) & .50 & & \\
\hline Hoods phlox (Phlox hoodii Richardson) & .28 & & \\
\hline Woolly plantain (Plantago patagonica Jacq.) & .28 & & \\
\hline Sandberg bluegrass (Poa sandbergii Vasey) & .28 & & \\
\hline Tumblegrass (Schedonnardus paniculatus) & .62 & .79 & .65 \\
\hline Scarlet globemallow (Sphaeralcea coccinea) & .73 & .76 & .60 \\
\hline \multicolumn{4}{|l|}{ Sand dropseed (Sporobolus cryptandrus (Torr.) } \\
\hline A. Gray) & .53 & .64 & .70 \\
\hline Needleand thread (Stipa comata) & .77 & .80 & .64 \\
\hline Green needlegrass (S. viridula) & .60 & .68 & .59 \\
\hline Bufalograss and blue grama & .69 & .80 & \\
\hline All cacti & .50 & & \\
\hline Increaser grasses & .63 & .60 & \\
\hline Decreaser grasses & .65 & .43 & \\
\hline All perennial grasses & .66 & .59 & \\
\hline Annual grasses & .16 & & \\
\hline Shrubs & .31 & & \\
\hline Increaser shrubs & .31 & & \\
\hline Total cover & .17 & & \\
\hline
\end{tabular}

'Calculations of $R^{2}$ values for plant year and growing-season precipitation were made only when $R^{2}$ values for calendar year precipitation exceeded 0.60 . 
determination $\left(R^{2}\right)$. Efforts were then undertaken to derive a more simplified and functional predictive equation by limiting the number of independent variables while still maintaining a reasonably high $R^{2}$ value $\left(R^{2}>0.70\right)$. Equations derived by this approach were more easily interpreted.

After identification of the best precipitation parameters, sets of regression equations were developed for each species in all treatments combined and individually for each of the 3 grazing intensities and the ungrazed areas. Regression equations were also developed for the following groups of species: buffalograss (Buchloe dactyloides (Nutt.) Engelm.) and blue grama (Bouteloua gracilis (Willd. ex HBK) Lag. ex Griffiths) combined, all perennial grasses together, all decreaser grasses, all increaser grasses, all annual grasses, all shrubs, all increaser shrubs, all cacti and total cover.

Predicted basal cover values were calculated using different precipitation levels for equations with $R^{2}>0.70$. Twenty-five combinations of previous and current annual precipitation were examined by using increments of $102,203,305,406$, and $508 \mathrm{~mm}(4,8$, 12,16 , and 20 inches, respectively) of annual precipitation. Some of these increments extrapolate beyond the range of precipitation which occurred during the study. Consequently, evaluation of such values required special care to insure that predicted values were reasonably consistent with what might be expected. Predicted values were used to graph three dimensional figures (response surfaces). These response surfaces were used to describe species responses to fluctuating precipitation over a 2-year period. Curves of each species were compared among grazing intensities to determine which grazing intensity provided an optimum amount of basal cover for forage. ${ }^{2}$

\section{Results and Discussion}

\section{Graphic Sereening}

After preliminary visual analysis of 142 species, 69 species were subjected to further evaluation by more detailed graphing methods. Subsequently, only 21 species showed sufficient relationships between cover and precipitation to merit in-depth analysis. These 21 species, however, were common constituents of the plant communities on the study site. These species were subjected to more detailed multiple regression procedures.

\footnotetext{
In this paper, we have employed the concept of optimum basal cover in reference to whether a plant species was desirable or undesirable as cattle forage. Large amounts of basal cover were considered optimal for desirable species with good forage value, such as western wheatgrass or green needlegrass; and small amounts of basal cover were considered optimal for species of poor forage value, such as red threeawn or scarlet globemallow.
}

\section{Multiple Regression}

For 6 of 9 species tested against all 3 precipitation regimes, largest $R^{2}$ values were obtained by using plant-year precipitation (Table 1); and except for western wheatgrass (Agropyron smithii Rydb.), it required fewer variables in the regression equation to achieve comparable $R^{2}$ values than did monthly growing season precipitation or calendar year precipitation. Therefore, plant-year precipitation was considered supcrior to other precipitation intervals, and it was used in all subsequent efforts to predict basal cover of individual species. When considering groups of species, $R^{2}$ values were greater using the calendar-year data, but $R^{2}$ values were relatively low for all groups. The only exception was for blue grama and buffalograss combined with $R^{2}=0.80$ on a plant-year basis and $R^{2}=0.69$ on a calendar-year basis. Because of low $R^{2}$ values, groups of species were not considered further.

Multiple regression analysis performed for each species and each grazing intensity resulted in $R^{2}>0.60$ for one or more of the individual stocking rates (Table 2). Equations with $R^{2}>0.70$ were obtained for 6 species when no livestock grazing occurred, and they were likewise derived for 8,7 , and 9 species, respectively under light, moderate, or heavy stocking rates.

Predictive equations were developed from regression equations for all species that had an initial $R^{2}>0.70$. If the actual precipitation variables had been eliminated by the stepwise process, they were added back into the regression equation to provide mathematical balance. In addition, variables that represented interaction responses could sometimes be removed from the regression equation without substantially reducing $R^{2}$ values. This was done to obtain simplified predictive equations with $R^{2}>0.70$. Associated $\mathbf{R}^{2}$ values that were obtained from this process are presented from each category in Table 3. Predicted values were than calculated from the resulting equations.

\section{Predicted Basal Cover and Response Curves}

Basal cover values that were predicted for each species were used to create response surfaces (Fig. 1-4) which provided an effective means of interpreting species response to precipitation combinations. By comparing response curves for the same species under different grazing intensities, the response of the species to grazing was also evaluated. Detailed discussion of the response of individual species can be found in Olson (1982).

Three general responses were exhibited by most species although individual variations between response surfaces occurred. The most frequent response was an increase in cover under either very high or very low precipitation regimes (Fig. 1 and 2). This response

Table 2. $R^{2}$ values obtained using plant-year precipitation parameters as independent variables and plant basal cover as the dependent variable for individual stocking rate treatments.

$R^{2}$

\begin{tabular}{|c|c|c|c|c|}
\hline \multirow[b]{2}{*}{ Species } & \multicolumn{4}{|c|}{ Stocking Rate Treatment } \\
\hline & None & Light & Moderate & Heavy \\
\hline Western yarrow & .81 & -1 & .23 & .42 \\
\hline Western wheatgrass & .51 & .78 & .97 & .88 \\
\hline Red threeawn & -1 & .92 & .81 & .89 \\
\hline Fringed sagewort & .59 & .84 & .74 & .69 \\
\hline Blue grama & .80 & .76 & .79 & .69 \\
\hline Buffalograss & .82 & .74 & .87 & .77 \\
\hline Threadleaf sedge & .62 & -1 & .62 & .70 \\
\hline Needleleaf sedge & .25 & .43 & .82 & .89 \\
\hline Pincushion cactus & .50 & .34 & .29 & .61 \\
\hline Tumblegrass & .77 & .78 & .35 & .94 \\
\hline Scarlet globemallow & .70 & .78 & .71 & .83 \\
\hline Sand dropseed & -1 & .66 & -1 & .53 \\
\hline Needleandthread & .62 & .84 & .60 & .84 \\
\hline Green needlegrass & .87 & .19 & .68 & .73 \\
\hline
\end{tabular}

'Species with no value recorded were not encountered under this stocking rate. 


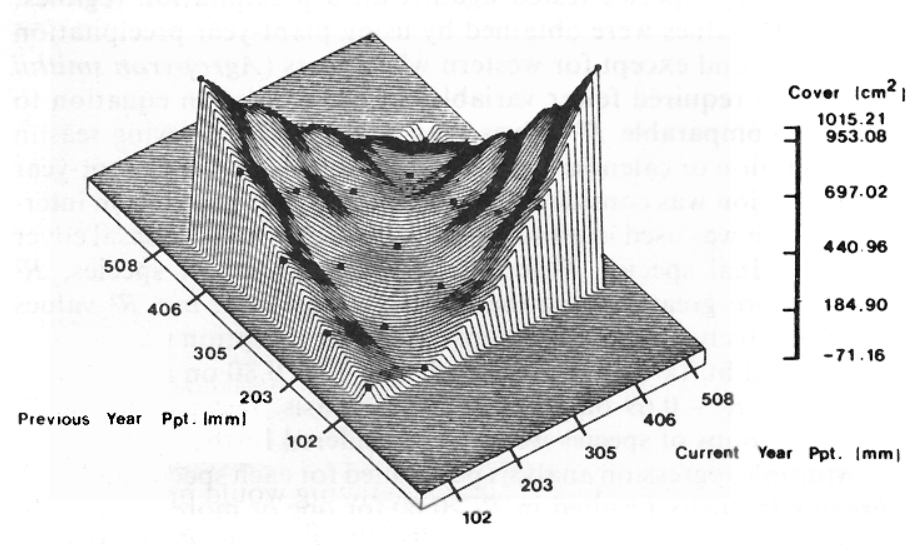

Fig. 1. Response of western wheatgrass basal cover to plant-year precipitation when lightly grazed. Cover $\left(\mathrm{cm}^{2}\right)$ is on the vertical axis and precipitation $(\mathrm{mm})$ for 2 consecutive plant years is on each horizontal axis.

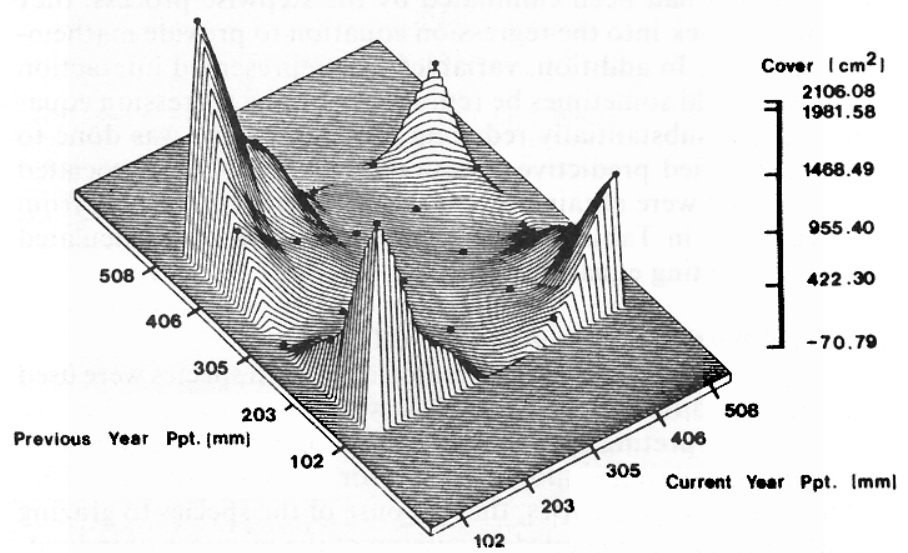

Fig. 2. Response of red threeawn basal cover to plant-year precipitation when lightly grazed. Cover $\left(\mathrm{cm}^{2}\right)$ is on the vertical axis and precipitation $(\mathrm{mm})$ for 2 consecutive plant years is on each horizontal axis.

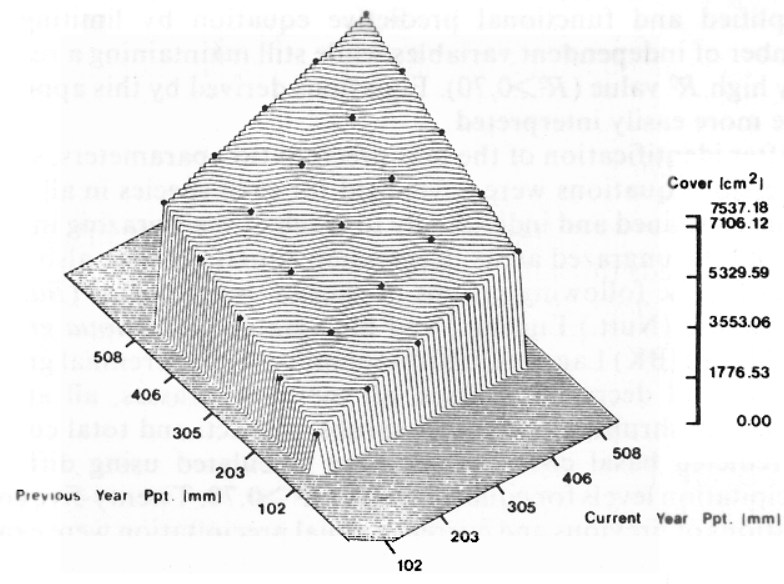

Fig. 3. Response of needleandthread basal cover to plant-year precipitation when considering all treatments combined. Cover $\left(\mathrm{cm}^{2}\right)$ is on the veritical axis and precipitation $(\mathrm{mm})$ for 2 consecutive plant years is on each horizontal axis.

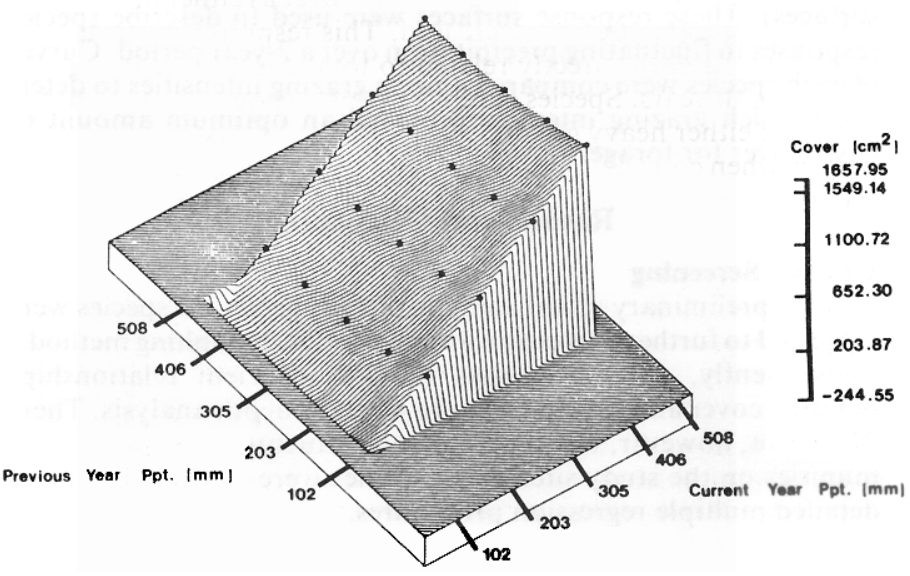

Fig. 4. Response of buffalograss basal cover to plant-year precipitation when moderately grazed. Cover $\left(\mathrm{cm}^{2}\right)$ is on the vertical axis and precipitation ( $\mathrm{mm})$ for 2 consecutive plant years is on each horizontal axis.

Table 3. $R^{2}$ values obtained for predictive equations after regression equations were simplified and mathematically balanced. Plant-year precipitation parameters were used as independent variables and plant basal cover as the dependent variable for each category.

\begin{tabular}{|c|c|c|c|c|c|}
\hline \multirow[b]{3}{*}{ Species } & \multicolumn{5}{|c|}{$R^{2}$} \\
\hline & \multicolumn{5}{|c|}{ Stocking Rate Treatment } \\
\hline & $\begin{array}{l}\text { All treatments } \\
\text { combined }\end{array}$ & None & Light & Moderate & Heavy \\
\hline Western yarrow & -1 & .72 & & & \\
\hline Western wheatgrass & .87 & & .78 & .87 & .87 \\
\hline Red threeawn & .75 & & .92 & .74 & .89 \\
\hline Fringed sagewort & .71 & & .73 & .74 & \\
\hline Blue grama & .72 & .75 & .76 & .79 & \\
\hline Buffalograss & .72 & .79 & .73 & .78 & .70 \\
\hline Threadleaf sedge & & & & & .70 \\
\hline Needleleaf sedge & & & & .77 & .74 \\
\hline Tumblegrass & .85 & .77 & .70 & & .87 \\
\hline Scarlet globemallow & .73 & .70 & .70 & .71 & .75 \\
\hline Needleandthread & .76 & & .75 & & .76 \\
\hline Green needlegrass & .70 & .82 & & & .73 \\
\hline
\end{tabular}

'Predictive equations were not developed for those categories showing an $R^{2}$ value of less than 0.70 in Tables 1 and 2 . 
was most frequently characterized by the highest points on the curve occurring where precipitation fluctuated from year to year (Fig. 1). On some curves, response surfaces were concave shaped with higher amounts of cover under extreme conditions and lower amounts under more average or normal precipitation conditions (Fig. 2). Species showing this response were western yarrow (Achillea millefolium L.), western wheatgrass, red threeawn (Aristida longiseta Steud.), blue grama, buffalograss when ungrazed or lightly grazed, needleleaf sedge (Carex eleocharis Bailey) when heavily grazed, threadleaf sedge (Carex filifolia Nutt.), tumblegrass (Schedonnardus paniculatus (Nutt) Trcl.), scarlet globemallow (Sphaeralcea coccinea (Nutt.) Rydb.) when ungrazed, and green needlegrass (Stipa viridula Trin.) when considering all treatments or when heavily grazed. It appeared that these species have an ability to respond to year-to-year fluctuations in precipitation that are common in this region. This may give them a competitive advantage in most years. Reduction in cover in these species under consistent, average precipitation conditions can probably be attributed to competition from species which are favored by less extreme precipitation fluctuation.

The second general type of response curve shows a direct relationship between cover and precipitation, regardless of the year in which precipitation occurred (Fig. 3). In this case, cover was greatest with 2 consecutive periods of high plant-year precipitation. There was an apparent linear decrease in cover as either previous or current year precipitation decreased. This response suggests that basal cover is most directly related to total cumulative precipitation for both years. Species exhibiting this response include buffalograss in either heavy grazing or for all treatments; scarlet globemallow when considering all treatments, light, moderate, or heavy grazing; needleandthread (Stipa comata Trin. \& Rupr.); and green needlegrass when ungrazed. These species apparently have an ability to respond to precipitation whenever it occurs during a 2-year period. Basal cover of these species appeared to be inversely related to cover of species showing the first response described. Reed and Peterson (1961) also noted that the cover of western wheatgrass and buffalograss were inversely related.

The third general type of response curve includes species which respond only to precipitation from either the previous or current year (Fig. 4). Precipitation in the alternate year has little effect on their basal cover. In these cases, as precipitation for the determining year increased, so did basal cover. This response can be subdivided into species that respond to previous year or current year precipitation. Fringed sagewort (Artemisia frigida Willd.) responded to previous year precipitation when lightly or moderately grazed. Species that responded to current year precipitation included buffalograss when moderately grazed and needleleaf sedge when moderately grazed.

Some species had response curves that were similar for all grazing intensities, while others showed a difference in their response to precipitation under different grazing intensities. This indicated that grazing pressure played a more important role in the response of such species. Moderate grazing appeared to be most favorable for optimum basal cover for the greatest number of species. Species with optimum cover under moderate stocking included western wheatgrass, red threeawn, fringed sagewort, blue grama, buffalograss, and needleleaf sedge. Scarlet globemallow attained optimum cover under heavy grazing, while needleandthread exhibited optimum cover under light grazing.

\section{Conclusions}

Each species reacted to precipitation regimes and grazing treatments in a distinctive manner. A species may respond differently to the same precipitation regime when subjected to different grazing intensities. Therefore, it is difficult to predict how cover of the entire plant community will react to a give precipitation regime. Species that are favored and disfavored will change in accordance with prevailing precipitation. Therefore, continual changes can be expected in species composition of the plant community as the precipitation regime fluctuates. For management purposes, domi- nant species in the plant community and their response to precipitation fluctuation need to be identified. However, when precipitation regimes change substantially, other species may become dominant, possibly affecting management decisions.

Many species respond positively to fluctuations and extremes in precipitation which occur frequently in the Northern Great Plains. Some species such as western wheatgrass or red threeawn obtain maximum cover when fluctuations and extremes occur, while others such as buffalograss or need leand thread respond quickly to any increases in precipitation.

Moderate grazing was more conducive to optimum basal cover for more of the species intensively studied than were other grazing intensities. This agrees with the findings of Reed and Peterson (1961) and Hurtt (1951), who recommended moderate grazing intensity for these ranges. Therefore, it appears that moderate stocking of 0.92 ha (2.3 acres) per AUM, or 5.52 ha (13.8 acres) per animal unit for 6 months of summer grazing would provide more favorable conditions for optimizing total plant basal cover than would other stocking rates. Because basal cover of species fluctuated from none or very little to the maximum amount due to changes in the precipitation regime, it is also apparent that stocking rate should be adjusted to coincide with a vailable forage. Basal cover is not a direct measurement of the forage available for livestock, but it does provide an index to the amount of plant basal material available to produce forage.

\section{Literature Cited}

Ahel, H., Iucille Rosenfield, and W.P. Stephens. 1962. Range feed forecasting. New Mexico. Agr. Exp. Sta. Bull. 462.

Albertson, F.W., A. Riegel, and J.L. Launchbaugh, Jr. 1953. Effects of different intensities of clipping on shortgrasses in western central Kansas. Ecology. 34:1-20.

Albertson, F.W., G.W. Tomanek, and A. Riegel. 1957. Ecology of drought cycles and grazing intensities on grasslands of the Central Great Plains. Ecol. Monogr. 27:27-44.

Clark, S.E., E.W. Tisdale, and N.A. Skoglund. 1943. The effects of climate and grazing practices on short-grass prairie vegetation in southern Alberta and southwestern Saskatchewan. Can. Dep. Agr. Tech. Bull. 46.

Cook, C.W., and P.L. Sims. 1975. Drought and its relationship to dynamics of primary productivity and production of grazing animals. p. 163168. In: Proceedings, Evaluation and Mapping of Tropical African Rangelands. Addis Ababa, Ethiopia.

Hill, R. 1920. Charting quadrats with a pantograph. Ecology. 1:270-273.

Herbel, C.H., F.N. Ares, and R.A. Wright. 1972. Drought effects on a semi-desert grassland range. Ecology. 53:1084-1093.

Holscher, C.E., and E.J. Woolfolk. 1953. Forage utilization by cattle on Northern Great Plains ranges. USDA Circ. 918.

Houston, W.A., and R.R. Woodward. 1966. Effects of stocking rates on range vegetation and beef cattle production in the Northern Great Plains. USDA Tech. Bull. 1357.

Hurtt, L.C. 1951. Managing Northern Great Plains cattle ranges to minimize effects of drought. USDA Circ. 865.

Johnson, J. 1981. Kange dry spells - yesterday, today, tomorrow. p. 68-88. In: Proceedings, The Range Beef Cow Symposium VII, Rapid City, SD, Dec. 7-9.

Olson, K.C. 1982. Effect of precipitation on mixed grass plant communities of southeastern Montana and its implications for grazing intensity. M.S Thesis, Montana State Univ., Bozeman.

Reed, M.J., and R.A. Peterson. 1961. Vegetation, soils, and cattle responses to grazing on Northern Great Plains range. USDA Forest Serv. Tech. Bull. 1252

Sarvis, J.T. 1941. Grazing investigations on the Northern Great Plains. North Dakota Agr. Exp. Sta. Bull. 308.

Schumacher, C.M. 1974. The Great Plains-wet or dry. J. Soil and Water Conserv. 29:156-159.

Smoliak, S. 1956. Influence of climatic conditions on forage production of shortgrass rangeland. J. Range Manage. 9:89-90.

Sneva, F.A., and D.N. Hyder. 1962. Estimating herbage production on semiarid ranges in the Intermountain Region. J. Range Manage. 15:88-93.

Weaver, J.E., and F.E. Clements. 1938. Plant ecology. 2nd ed. McGrawHill Book Co., Inc., New York.

Whitman, W., H.C. Hanson, and R.A. Peterson. 1943. Relation of drought and grazing to North Dakota rangelands. ND Agr. Exp. Sta. Bull. 320. 